О.Б. Черних

О.О. Мітягін, полковник,

НУОУ імені Івана Черняховського

Ю.О. Черних, кандидат технічних наук, доцент,

ВІКНУ імені Тараса Шевченка

\title{
АНАЛІЗ СУЧАСНОГО СТАНУ СИСТЕМИ ВІЙСЬКОВОЇ ОСВІТИ РЕСПУБЛІКИ ПОЛЬЩА: ДОСВІД ДЛЯ УКРАЇНИ
}

У статті розглянуто досвід підготовки військових фахівичів для збройних сил республіки Польщза. Розглянуто основні напрями реформи військової освіти. Проведено аналіз існуючої мережі військових навчальних закладів для підготовки офічерів тактичної, оперативно-тактичної та оперативно-стратегічної ланок військового управління, а також для підготовки унтер офіцерів. Визначені основні вимоги, щуо висуваються до рівня знань та навичок випускників вищих військових навчальних закладів з освітніми рівнями бакалавра $і$ магістра. Наведено відомості щзодо чисельності щорічного прийому до вищих військових навчальних закладів за певними напрямами підготовки. Означені варіанти організаџії підготовки офічерів на первинні посади з урахуванням освітнього рівня, щзо здобувається. Визначено основні переваги та недоліки, щуо існують в системі військової освіти Польщі.

Ключеві слова: система військової освіти; збройні сили Польщі; мережа військових навчальних закладів; досвід підготовки офічерів.

Постановка проблеми. Реформа вищої військової освіти в Україні триває в руслі загальноєвропейського розвитку. Творче використання міжнародного досвіду підготовки офіцерських кадрів за кордоном набуває особливої актуальності в умовах впровадження стандартів НАТО у Збройних Силах України. Тому, в сучасних умовах, позитивні елементи досвіду зарубіжних армій повинні бути використані в підготовці офіцерського складу українських Збройних Силах (3С). При цьому безумовно необхідно не просто копіювати освітні моделі інших країн, а враховувати досвід, традиції української військової школи, національні особливості становлення і розвитку вітчизняних Збройних Сил.

Основними завданнями подальшого розвитку військової освіти $\epsilon$ формування адекватної реформуванню 3С України системи підготовки офіцерських кадрів, виведення їі на якісно новий рівень з урахуванням змін у національній системі вищої освіти в руслі вимог Болонського процесу, Національної стратегії розвитку освіти, Закону України «Про вищу освіту», приведення всіх іiі параметрів у відповідність до сучасних вимог, забезпечення оптимального формування та розвитку офіцерських кадрів, їх інтелекту, професіоналізму, креативних здібностей, усіх видів компетентностей, загальної та військово-професійної культури, надання процесу підготовки випереджального й гнучкого характеру відповідно до завдань і функцій 3С України у державі та їх участі у миротворчих операціях і в зоні антитерористичної операції.

Виходячи 3 цього, особливої актуальності набуває проблема поглиблення та розширення наукового супроводження розвитку системи підготовки військових фахівців різних ланок військового управління. У 
статті аналізується досвід підготовки офіцерів у збройних силах Республіки Польща, що виконаний під час проведення дослідження у рамках науководослідної роботи «Удосконалення національної системи військовій освіті відповідно до стандартів підготовки фахівців у навчальних закладах країнчленів НАТО» (шифр - Підготовка-Н).

Аналіз досліджень і публікацій. Дослідженню питань, що пов'язані 3 аналізом систем підготовки військових фахівців інших країн, присвячено низку наукових праць вітчизняних науковців. Зокрема, загальні проблеми підготовки військових спеціалістів досліджуються у наукових працях Барабанщикова О.В., Кандибовича Л.О., Літвіновського С.Ю., Маслова В.С., Машталіра А.М., Нещадима М.І., Стефаненка П.В., Приходька Ю.І., Хорєва I.O., Ягупова В.В., професійної підготовки військовослужбовців Агапова Т.П., Бойка О.В., Варія М.Й., Іщенка Д.В., Каменева А.І., Красильника Ю.С., Кривоноса О.Б., Машталіра А.М., Олексієнко Б.М., Радванського І.Г., Сороки Г.І., Тихончука А.О., Челпанова О.С., професійної діяльності офіцера - Алтухова П.К., Давидова В.П., Маслова Б.Б., М'ясникова В.О., Пантюка О.В., Рейші О.Е., Руснака I.С., Смолікова І.Й., Столяренка О.М., Студентові В.Ф., Телелима В.М., Філоненка Г.П., педагогічних аспектів діяльності військових кадрів - Аксьонова О.М., Зельницького А.М., Козубцова I.М., Моісєєва В.Г., Тарнавського М.М.

Аналіз досліджень і публікацій щодо питання, яке досліджується, дозволяє зробити висновок, що, незважаючи на відмінності, котрі традиційно склалися у системах військової освіти України, провідних європейських країнах і США, представляється можливим виділити загальні тенденції розвитку вищої військової школи в XXI столітті: поліпшення відбору кандидатів для навчання у вищих військових навчальних закладах (ВВН3), стабілізація їх числа на сучасному рівні; диференціація структурних підрозділів ВВН3; запровадження компетентністного підходу до формування змісту навчання, персоніфікація змісту підготовки тих, хто навчається, подальша його інформатизація, впровадження мультимедійних засобів навчання тощо.

Серед країн-членів НАТО, поруч з американською системою підготовки офіцерських кадрів найбільш широко досліджується знаменита трійка країн Великобританія, Німеччина, Франція, авторитет військової освіти яких поширюється на весь європейський континент і далії. I це закономірно. Військові освітні системи, що побудовані в них, на цей час є незаперечним зразком. Адаптованість цих систем до динамічних змін у замовленні на підготовку військових фахівців, якісні професійно-кваліфікаційні параметри, що відповідають потребам сучасних збройних сил, економічна доцільність побудови мережі військових навчальних закладів виступають як визначальні чинники авторитету згаданих систем військової освіти. Разом з цим, реформі системи підготовки офіцерських кадрів у збройних силах Польщі, що до початку 90-х років минулого століття була побудована за однаковими принципами 3 українською системою військової освіти, присвячено недостатньо публікацій. 
Метою статті $\epsilon$ проведення аналізу сучасного стану системи військової освіти Республіки Польща для врахування досвіду з підготовки офіцерських кадрів для подальшої реформи національної системи військової освіти.

\section{Виклад основного матеріалу.}

Система навчання, що створена в освітніх установах $\mathrm{i}$ центрах національних збройних сил Республіки Польща (РП), націлена на досягнення максимальної відповідності вимогам Північноатлантичного союзу.

На початку 90-х років минулого століття у РП існувало 16 ВВНЗ, зокрема - 5 академій та 11 вищих військових училищ. Майже кожний вид та род збройних сил мав відповідний вищий військовий навчальний заклад за певною спеціальністю. До системи військової освіти також належали 21 військова школа (19 шкіл прапорщиків та 2 школи сержантів) [1]. Скорочення чисельності особового складу збройних сил РП вимагало скорочення кількості ВВНЗ. Тому система військової освіти Польщі, починаючи 3 початку 90-х років, знаходиться у стані постійного реформування.

У 2012 році керівництво міністерства оборони країни представило черговий проект концепції реформування системи військової освіти. Було передбачено, що заплановані заходи з реформування будуть здійснюватися в два етапи: на першому (до кінця 2012 року) була підготовлена і створена необхідна законодавча база, а на другому (2013-2015 роки) планувалося повністю завершити перехід до нової системи військової освіти [2].

Програмою було передбачено, що підготовка офіцерів для збройних сил РП буде здійснюватися в єдиному військовому навчальному закладі Університеті національної оборони, який планувалося сформувати на базі: Академії національної оборони; Військової технічної академії; Академії військово-морських сил, частини Вищої офіцерської школи повітряних сил, частини Вищої офіцерської школи сухопутних військ і частини Військовомедичного інституту.

Крім того, на базі Вищої офіцерської школи повітряних сил планувалось створити Центр підготовки фахівців повітряних сил, на базі Вищої офіцерської школи сухопутних військ - Центр підготовки фахівців сухопутних військ, на базі Академії військово-морських сил - Центр підготовки фахівців військово-морських сил.

В основу програми реформування військової освіти було покладено такі основні принципи [3]:

основним навчальним закладом з підготовки кадрів у сфері міжнародної безпеки є Університет національної оборони;

основним науковим центром, який об'єднуватиме діяльність всіх військових науково-дослідних установ, $є$ Військова технічна академія (у складі Університету національної оборони);

координуючим органом системи військової освіти повинна стати Спілка військових навчальних закладів видів збройних сил; 
питаннями наукової роботи і методологічного забезпечення освітньої діяльності займається департамент науки і військової освіти міністерства оборони Польщі;

підготовка офіцерських кадрів на первинні посади здійснюється за двома освітніми рівнями.

Пізніше від зазначеної вище концепції частково відмовилися й внесли корективи до програми реформування. Так у 2016 році відмовилися від створення єдиного ВВНЗ для підготовки військових фахівців.

На сьогодні підготовка офіцерських кадрів у збройних силах РП, в основному, здійснюється у військових навчальних закладах, до яких відносяться: Військово-технічна академія у м. Варшава, Військова академія сухопутних військ ім. генерала Тадеуша Костюшка у м. Вроцлаві; Академія військово-повітряних сил у м. Демблін; Військово-морська академія в м. Гдиня; Академія воєнного мистецтва (колишня Академія національної оборони) у м. Варшава [4].

Чисельність осіб, які приймаються на навчання до вищих військових навчальних закладів щорічно визначається наказом міністра національної оборони РП. Так у 2015 році на навчання до ВВНЗ для підготовки офіцерів на первинні посади було прийнято 520 курсантів. Більшість 3 них, понад 280 осіб, розпочали підготовку у Військової технічної академії, до Військової академії сухопутних військ прийнято 144 курсанти, до Академії ВПС - 61 курсант, до Академії ВМС - 28 курсантів.

У 2016 році на навчання було прийнято 534 особи, зокрема до Військової технічної академії - 280 осіб (напрями підготовки: електроніка та телекомунікації - 92 особи, інформатика - 50 осіб, мехатроніка - 27 осіб, аерокосмічний -25 осіб, будівництво - 25 осіб, криптографія та кібербезпека - 15 осіб, хімічні речовини - 15 осіб), до Військової академії сухопутних військ прийнято 150 курсантів, до Академії ВПС - 74 курсант (напрями підготовки: навігація -10 осіб, логістика -4 особи, льотний - 60 осіб), до Академії ВМС - 30 курсантів (напрями підготовки: навігація -10 осіб, інформатика - 10 осіб, механіка та машинобудування - 5 осіб, мехатроніка 5 осіб) [5].

Кандидати на навчання у ВВНЗ до 31 березня поточного року повинні зареєструватися у ВВНЗ та відповідати наступним вимогам: бути громадянином Польщі, віком понад 18 років, мати диплом про середню освіту, добрий стан здоров'я, не мати судимості.

Основними вимогами до підготовки військових фахівців $є$ [6]:

І освітній рівень (бакалавр).

Підготовка кандидатів на офіцерські посади з метою надання їм знань i вмінь для виконання ними службових обов'язків на первинних посадах системи управління відповідного роду військ. Зазначена підготовка повинна надати навички 3 управління невеликими підрозділами (командир взводу тощо).

Програма підготовки зазначених кадрів охоплює і забезпечує надання таких знань: обов'язкові навчальні дисципліни (необхідні для отримання 
вищої освіти); основні положення щодо діяльності військ за спеціальністю; загальні знання щодо збройних сил і виду військ; знання щодо призначення i діяльності роду військ, в якому офіцер буде проходити військову службу після закінчення навчання; загальновійськова тактика і тактика дій роду військ; головні напрями управління невеликими підрозділами (група, взвод) у мирний час, у загрозливий період і під час воєнного стану; тактико-бойові можливості та принципи застосування роду військ; основні положення щодо організації і методики проведення підготовки солдата, відділення, взводу.

\section{ІІ освітній рівень (магістр).}

Підготовка повинна забезпечити глибокі знання професійного офіцера, які забезпечуватимуть йому можливість брати участь у процесах прийняття рішень і управлінні підпорядкованими підрозділами у системі управління виду збройних сил (роду військ) на тактичному рівні. Крім цього, повинні надаватись основні знання оперативно-тактичного рівня.

Програма підготовки зазначених офіцерських кадрів повинна охоплювати і забезпечувати надання таких знань: поглиблене бачення щодо завдань і діяльності збройних сил, грунтовні знання про вид збройних сил; грунтовні бачення і навички, пов'язані з управлінням підрозділами різних видів збройних сил (родів військ), а також управління військовими підрозділами (частинами), підсиленими ротою, батальйоном (або рівнозначними); теоретичні основи і практичні навички оцінки ситуації та прийняття рішення; обов'язкові процедури, які здійснюються в штабах НАТО; бойові можливості та основи застосування роду військ в різних умовах бойової обстановки; загальні основи оперативного мистецтва i тактики різних родів військ відповідного виду збройних сил; основи організації і методика проведення підготовки (проведення навчань) частин i 3'єднань.

На теперішній час модель навчання, яка прийнята у системі військової освіти РП, визначає шість можливих варіантів отримання першої офіцерської посади з моменту здобуття особою атестату про середню освіту:

1 варіант - освітній рівень бакалавра здобувається у ВВНЗ за військовим напрямом (призначений для підготовки офіцерів 3 пріоритетною військовою підготовкою, у першу чергу, командного складу тактичного рівня);

2 варіант - освітній рівень магістра здобувається у ВВНЗ за військовим напрямом (призначений для підготовки офіцерів 3 технічних напрямів підготовки, що призначаються на посади з науковою спрямованістю);

3 варіант - освітній рівень магістра здобувається у ВВНЗ за цивільним напрямом (призначений для підготовки офіцерських кадрів, посади яких вимагають наявність освітнього рівня “магістр”. В основному, застосовується для підготовки офіцерів логістики, озброєння і військової техніки тощо);

4 варіант - освітній рівень бакалавра здобувається у цивільному ВНЗ, підготовка за освітнім рівнем магістра відбувається у ВВНЗ (призначений для підготовки офіцерів, посади яких вимагають наявність освітнього рівня "магістр". В основному, застосовується для підготовки офіцерів 3 логістики, озброєння і військової техніки тощо); 
5 варіант - освітній рівень бакалавра здобувається у цивільному ВНЗ 3 подальшим проходженням навчальних курсів у офіцерських школах (навчальних центрах) (стосується напрямів підготовки офіцерів, навчання яких за їх спеціальностями недоцільно проводити у ВВНЗ. Крім того, підготовка за цим варіантом дозволяе створити відповідний потенціал реагування на збільшення потреб в офіцерських кадрах);

6 варіант - освітній рівень магістра здобувається у цивільному ВНЗ 3 подальшим проходженням випускниками вищого навчального закладу офіцерських курсів у ВВНЗ (стосується вузької групи спеціальностей право, військові лікарі, фармакологія, теологія тощо).

Останнім часом, у збройних силах РП значно підвищена роль унтерофіцерів [2]. Згідно з розпорядженням міністра національної оборони РП «3 питання про унтер- офіцерські навчальні заклади» від 6 серпня 2010 року здійснено перехід на нову систему підготовки унтер-офіцерів. Раніше вона проводилася в чотирьох унтер-офіцерських школах (м. Вроцлав, м. Познань, м. Торунь і м. Зегже), які підпорядковувалися безпосередньо командувачу сухопутних військ. Він був безпосереднім розробником систем підготовки, перепідготовки та підвищення кваліфікації унтер-офіцерського складу.

Нещодавно було проведено об'єднання унтер-офіцерських шкіл на базі однієї з них в м. Познань. На цю школу покладені такі завдання: підготовка унтер-офіцерів 3 загальновійськових дисциплін, вивчення особливостей сучасного бою, методики командування відділенням, а також окремих питань міжнародного права; організація курсів перепідготовки та підвищення кваліфікації військовослужбовців цього складу; підготовка добровольців (відповідно до потреб), що дозволить поповнювати унтер- офіцерські кадри в структурах територіальної оборони.

За загальною програмою навчання унтер-офіцерів відповідає начальник Центру підготовки сухопутних військ (м. Познань), а за спеціальну підготовку - начальники відповідних центрів, в залежності від спеціальності.

Новою навчальною програмою підготовки унтер-офіцерського корпусу, введеної з 1 січня 2011 року, на відміну від колишньої, не передбачена можливість набору кандидатів в унтер-офіцери з цивільної молоді. Він здійснюється з числа військовослужбовців, які пройшли тримісячний курс основної підготовки, при цьому подальша їх підготовка триває дев'ять місяців, відповідно.

Центрам підготовки за фахом відводиться роль основних організаційних одиниць системи військової освіти професійних військовослужбовців, перепідготовки та підвищення кваліфікації унтер-офіцерів, а також фахівців для сил територіальної оборони. Зокрема, підготовку фахівців для підрозділів сухопутних військ проводять такі навчальні центри: сухопутних військ (м. Познань і м. Дравсько); артилерії (м. Торунь); інженерних військ і РХБЗ (м. Вроцлав); зв'язку та інформаційних систем (м. Зегже); медичної служби (м. Лодзь); центр підготовки до участі в іноземних військових місіях (м. Кельце); гірської підготовки (м. Душніки-Здруй); підготовки танкістів (м. Швентошув); підготовки снайперів (м. Венджін); підготовки фахівців 
ВДВ (м. Лежниця). Інфраструктура для відпрацювання практичних навичок включає в себе ряд полігонів: "Венджін", "Дравсько-Поморське", "Жагань", "Нова Демба", "Бемовописк", "Віцко-Морську", "Душніки-Здруй" і "Ожиш".

Об'єднаний центр бойової підготовки об'єднаних збройних сил (ОЗС) HATO (м. Бидгощ) займає особливе місце в системі підготовки військових фахівців тактичного рівня. Він підпорядкований стратегічному командуванню реформування ОЗС альянсу (штат Норфолк, США). Основними завданнями цього центру є: надання допомоги в організації бойової підготовки ОЗС НАТО та їхніх союзників; підготовка кадрів для ЗС нових членів альянсу, перш за все, країн Східної Свропи; досягнення повної взаємодії підрозділів національних ЗС при виконань завдань у складі міжнародних контингентів; підготовка органів управління і підрозділів тактичної ланки, що входять в контингенти сил швидкого реагування НАТО.

Крім підготовки підрозділів до виконання завдань у складі сил швидкого реагування блоку або інших міжнародних контингентів персонал центру займається аналізом їх діяльності, вдосконаленням планів бойової підготовки, подальшим розвитком концепцій і доктрин НАТО в сфері застосування багатонаціональних сил. Військово-політичне керівництво РП, 3 огляду на дані обставини, в грудні 2011 року сформувало Центр доктрин і бойової підготовки ЗС Польщі (м. Бидгощ). Він же виконує функцію військово-професійної підготовки офіцерів сухопутних військ країни.

Підготовка офіцерів оперативно-тактичної та оперативно-стратегічної ланок управління у збройних силах РП здійснюється в Академії воєнного мистецтва [7]. Разом 3 підготовкою офіцерів академія здійснює навчання цивільних фахівців у галузі національної безпеки та оборони В цей час вона $€$ найбільшим нетехнічним вищим навчальним закладом Польщі серед ВНЗ, які готують фахівців для збройних сил, державних установ і приватного сектора. Крім підготовки кадрів, академія $є$ науково-дослідним центром.

До 2016 року в складі академії існували факультети: стратегічнооборонний; сухопутних військ; військово-повітряних сил і протиповітряної оборони; гуманітарних наук; менеджменту i управління; національної безпеки. При цьому станом на 1 січня 2016 року в академії навчалася переважна більшість цивільних осіб. Основні напрями навчання: національна безпека; внутрішня безпека; міжнародна безпека; державне управління; інформаційна безпека; матеріально-технічне забезпечення; управління економікою; управління авіацією.

Зміст навчальної програми спрямований на оволодіння офіцерами методикою самостійного прийняття рішень на різних командних рівнях в інтересах оперативного планування натовських операцій з підтримки миру в рамках мандата $\mathrm{OOH}$, а також на розробку детального оперативного плану розгортання i застосування загальновійськових об'єднаних оперативнотактичних груп. Виховне значення спільного навчання полягає в демонстрації слухачам взаємозв'язку i взаємозалежності національних політичних рішень від загальнонатовскіх інтересів, участі в реалізації 
прийнятих рішень різних громадських організацій, в формуванні у офіцерів умінь і навичок планування операцій в об'єднаних штабах.

Висновки. За оцінкою польських фахівців, існуюча система військової освіти Польщі має ряд переваг, а саме: дозволяє, у разі необхідності, створити значний кадровий потенціал для збройних сил; забезпечує потреби у сфері підготовки військовослужбовців для проходження професійної військової служби та удосконалення професійної підготовки офіцерських кадрів; має значний науковий потенціал у сфері військової техніки i національної безпеки; має значний матеріально-технічний потенціал (інфраструктура, забезпечення лабораторій); існує можливість отримання фінансових ресурсів на утримання військових навчальних закладів за межами міністерства оборони.

В той же час польські експерти відмічають низку недоліків такої системи, зокрема: значна перевага у чисельності цивільних студентів над чисельністю військових курсантів (слухачів), які навчаються у ВВНЗ; розвиток комерційної освіти без виконання вимог правових актів; значне зростання адміністративного складу ВВН3; провал програми пошуку офіцерських кадрів серед випускників цивільних ВНЗ; відсутня чітка концепція використання у збройних силах наукового потенціалу цивільних вищих навчальних закладів; недостатній рівень інвестицій 3 боку міністерства оборони РП в розвиток системи військової освіти; система удосконалення професійної підготовки офіцерів вимагає змін у зв'язку 3 надмірним обтяженням тих, хто навчається, i необгрунтованою довготривалістю деяких форм навчання; система підготовки офіцерських кадрів практично не використовує набутий у закордонних місіях досвід; недостатньо організована координація програм підготовки кадрів між окремими військовими навчальними закладами.

\section{ЛІТЕРАТУРА}

1. Wojownicy" do szkolenia potrzebni od zaraz. [Електронний ресурс]. - Режим доступу: http://www.polska-zbrojna.pl/home/articleshow/18772?t=-Wojownicy-do-szkoleniapotrzebni-od-zaraz.

2. Ministerstwo Obrony Narodowej [Електронний pecypc]. - Режим доступу http://www.mon.gov.pl/.

3. Military Higher Schools in Polish Army. [Електронний ресурс]. - Режим доступу: http://www.nauka.gov.pl/en/higher-education-institutions/milita-ryhigher-schools.html.

4. The General Tadeusz Kosciuszko Military Academy of Land Forces Wroclaw - Poland. [Електронний pecypc]. - Режим доступу: http://www.armyacademy.ro/iMAF/Sites/doc/Institution_WROCLAW.pdf.

5. Ponad pół tysiąca miejsc na studia w mundurze. [Електронний ресурс]. - Режим доступу: http://www.polska-zbrojna.pl/home/articleshow/18627?t=-Ponad-pol-tysiaca-miejscna-studia-w-mundurze.

6. MON: Uczelnie wojskowe mają być elitarne. [Електронний ресурс]. - Режим доступу: http://www.polska-zbrojna.pl/home/articleshow/18771?t=MON-Uczelnie-woj-skowemaja-byc-elitarne.

7. Nowy rektor wrocławskiej Szkoły Oficerskiej [Електронний ресурс]. - Режим доступу: http://www.polska-zbrojna.pl/home/articleshow/18316?t=Nowy-rektor-wroclawskiejSzkoly-Oficerskiej. 
О.Б. Черных

О.А. Митягин, полковник,

НУОУ имени Ивана Черняховского

Ю.О. Черных, кандидат технических, доцент

ВИКНУ имени Тараса Шевченко

\section{АНАЛИЗ СОВРЕМЕННОГО СОСТОЯНИЯ СИСТЕМЫ ВОЕННОГО ОБРАЗОВАНИЯ РЕСПУБЛИКИ ПОЛЬША: ОПЫТ ДЛЯ УКРАИНЫ}

В статье рассмотрен опыт подготовки военных специалистов для вооруженных сил республики Польша. Рассмотрень основные направления реформы военного образования. Проведен анализ существующей сети военных учебных заведений для подготовки офицеров тактического, оперативно-тактического и оперативностратегического уровней военного управления, а также для подготовки унтер офицеров. Определены основные требования, предъявляемые $\kappa$ уровню знаний и навыков выпускников высших военных учебных заведений с образовательными уровнями бакалавра и магистра. Приведены сведения о численности ежегодного приема в высшие военные учебные заведения по соответствующим направлениям подготовки. Указанны варианты организации подготовки офицеров на первичные должности с учетом приобретаемого образовательного уровня. Определены основные преимущества и недостатки, существуюшие в системе военного образования Польши.

Ключевые слова: система военного образования; вооруженные силь Польши; сеть военных учебных заведений; опыт подготовки офищеров.

O.Chernykh,

O. Mitaygin

NDUU named after Ivan Chernyakhovsky

J.Chernykh, PhD in technical sciences, Associate Professor,

Military institute of Taras Shevchenko National University of Kiev

\section{THE CURRENT STATE ANALYSIS OF THE MILITARY EDUCATION SYSTEM OF THE REPUBLIC OF POLAND: EXPERIENCE FOR UKRAINE}

The article deals with the experience of military specialists' training for the armed forces of the Republic of Poland. Basic trends of the military education reform have been considered. The analysis of existing network of military educational establishments for training of officers of tactical, operational-tactical and operational-strategic levels as well as non-commissioned officers' training has been performed. Level of knowledge and skills requirements for the military higher educational institutions' graduates with bachelor and master educational level have been determined. The information about military higher educational institutions' annual enrolment number for specific training directions is given. Main advantages and disadvantages of Polish military education system have been considered.

Key words: military education system; armed forces of the Republic of Poland; network of military educational establishments; officers' training experience. 